\title{
A Discourse on Belarusian Music and its Role in the Construction of Identities in Belarus
}

\author{
Anastasia Wakengut
}

\section{Introduction: Belarusian Identities}

Belarus, a post-Soviet state in the heart of Eastern Europe, is characterized by the complexity of historical and cultural impacts. Before it became independent in 1991, Belarus belonged to and was culturally influenced by different regions, such as the Grand Duchy of Lithuania, Polish-Lithuanian Commonwealth, the Russian Empire and, finally, the Soviet Union. ${ }^{364}$ The Russification policy of the Russian Empire marginalized the Belarusian language, and the process of marginalization continued in Soviet Belarus. Officially, Belarus has two state languages - Belarusian and Russian. However, Russian is widely used, while Belarusian remains marginalized: only a minority of Belarusians speak the language in everyday life. This minority often evokes controversial reactions: it is either politicized and linked with opposition or associated with rural people. ${ }^{365}$

Different scholars describe Belarusian national identity as "malleable" 366 or as "less well developed" than in neighboring states. ${ }^{367}$ It is evident, however, that two different conceptions of national identity exist in Belarus. Nelly Bekus describes these opposing discourses as "the official and the alternative Belarusianness." ${ }^{368}$ This model suggests that the nation, which is ethnically Belarusian in the vast majority, is split into two different

364 Cf. Thomas M. Bohn, Victor Šadurskij, and Albert Weber, eds., Ein weißer Fleck in Europa: Die Imagination der Belarus als Kontaktzone zwischen Ost und West (Bielefeld: Transcript Verlag, 2011), 9-12.

365 The latter are also often associated with the so-called Trasyanka, a mixed Belarusian-Russian variety of the language.

366 Cf. Andrew Wilson, Belarus: The Last Dictatorship in Europe (New Haven: Yale Univ. Press, 2011).

367 Cf. David R. Marples, Belarus: A Denationalized Nation (Amsterdam: Harwood Acad. Publ., 1999).

368 Nelly Bekus, Struggle over identity: the official and the alternative "Belarusianness" (Budapest: CEU Press, 2010). 
political nations. Each of them employs its own identity politics, discourses, symbols, and cultural practices to express itself. The "alternative Belarusianness" involves the engagement in Belarusian pre-Soviet history, usage of the Belarusian language, anti-establishment discourses and cultural practices, and post-colonial positioning. On the contrary, the "official Belarusianness" relates to the idea of national identity as maintained by the official "pro-Soviet" discourse and embraced by a larger, Russian-speaking part of Belarusians. ${ }^{369}$

The issue of national identity is inextricably linked with the issue of the Belarusian language, and these issues remain in the foreground at different levels - not only at the academic level but also at the social and cultural ones. As a post-Soviet state, Belarus continues to preserve the cultural legacy of the Soviet past. At the same time, many young Belarusians strongly identify with Europeans in different ways. Processes of identity construction are extremely multifaceted and can be described as "transcultural." ${ }^{370}$ Analyzing the eclectic "identity projects," and the diverse perceptions of Belarusian culture as articulated through cultural practices such as music, one can develop an understanding of current issues, and specifically the issue of identity, in Belarus.

\section{Methodological Framework}

The article emerged in the framework of a dissertation project, "Popular Music and the Construction of Cultural Identities in Post-Soviet Belarus," 371 conducted in the context of the interdisciplinary post-graduate studies programme with the title "The Construction

369 However, Belarusian speakers should not automatically be associated with certain political views, as Russian speakers should not necessarily be linked with conformism.

370 Cf. Wolfgang Welsch, "Transculturality: the Puzzling Form of Cultures Today," in Spaces of Culture: City, Nation, World, eds. Mike Featherstone and Scott Lash (London: Sage, 1999), 194-213. According to the theory of transculturality, cultures are not closed, homogeneous, uniform national entities or communities, but represent a plurality of possible identities. The concept implies that transcultural cultures do not just coexist but are interpenetrative and are thus "hybrid."

371 The term "popular music" as a common term in Popular Music Studies is neutral and is used to describe various genres and styles of music. Popular music is commonly understood as music that began to develop with the growth of industrialization in the $19^{\text {th }}$ century and reached broader audiences by the 1950 s, as sheet music was completely replaced by vinyl records. Popular music can be defined as "readily comprehensible" to a large amount of people with no obligatory knowledge of musical theory and techniques: cf. Stanley Sadie, ed. The New Grove Dictionary of Music and Musicians (London: Macmillan, 1980), 87.

In the present study, popular music is understood as a discursive practice that offers cultural meanings and thus participates directly in the construction of identities: cf. Peter Wicke, Vom Umgang mit Popmusik (Berlin: Cornelsen, 2001).

"Identity" is understood here as a process, which indicates its continuing, flexible, non-stable and changeable character. Identity can be described as a "becoming" or process, rather than a fixed entity involving the "suturing" of the "discursive outside" with the internal processes of subjectivity: cf. Stuart Hall, "The Question of Cultural Identity," in Modernity: an Introduction to Modern Societies, ed. Stuart Hall et al. (Oxford: Blackwell Publishers, 1996), 595-634. 
of Identities of Young Adults in a Post-Socialist Society in Transformation: The Case of Belarus." 372

The article is based on research involving participant observation, twenty-one semistructured guided interviews, and two focus groups, all conducted in Minsk, Belarus. Throughout three stays in Minsk in 2013 and 2014 (about ten weeks in total), I did "field work" that can be described as ethnographic research with a focus on young people and their music preferences. In the study, I approach music as "a key to identity [offering] a sense of both self and others," 373 and as "a resource in [which] and through which agency and identity are produced." ${ }^{374}$ Without giving preference to a specific genre, I place a "microsociological" focus upon people and their musical practices in the attempt to recognize "the ways in which music is used and the important role that it plays in everyday life and in society generally." 375

Statistical data are provided by a survey which was developed by the members of the post-graduate studies programme in cooperation with the Center of Social and Political Investigations (CSPI) of the Belarusian State University, Minsk. The representative, nation-wide survey consists of standardized interviews with 1000 Belarusians, aged 18 to 30 (representing 493 female and 507 male respondents). The CSPI conducted the survey in late $2013 .{ }^{376}$

Sixteen focus group respondents as well as thirteen interviewees were recruited by the CSPI, whose networks are broad enough to offer a wide range of representatives of Belarusian youth with various possible music preferences. In addition, one interviewee was an acquaintance that I made at a concert. ${ }^{377}$ The remaining seven interviewees were recruited through my personal network in Minsk, and were selected based on a strong identification with a particular music style (or styles). The selection method can thus be described as snowball sampling, which enables the researcher to get access to the inner structure of the field and, ideally, to the contrasts in the field, ${ }^{378}$ which appeared to be the case in this research.

372 In the studies programme, a combination of quantitative and qualitative methods is applied. Description of the project: https://www.uni-oldenburg.de/hlk-belarus/.

373 Simon Frith, "Music and Identity," in Questions of Cultural Identity, eds. Stuart Hall and Paul du Gay (London: Sage, 1996), 110.

374 Tia DeNora, Music in Everyday Life (Cambridge: University Press, 2000), 5.

375 Sarah Cohen, "Ethnography and Popular Music Studies," Popular Music 12 (1993): 127.

376 The selection method that the CSPI applied was random-route sampling. The language of the survey was Russian as it is the language most-used among Belarusian population.

377 It was a punk rock concert in the Piraty club in Minsk, which made an impression of an underground club that was situated far from the center. The performing bands were Adaptatsiya from Kazakhstan and the famous Belarusian band Neyro Dyubel.

378 Cf. Aglaja Przyborski and Monika Wohlrab-Sahr, Qualitative Sozialforschung, 4th ed. (München: Oldenbourg, 2014). 
Given the project's focus on the construction of cultural identities in a post-Soviet society, focus group respondents were selected on the basis of their identification with "European" or "Cosmopolitan" culture. ${ }^{379}$ In other words, the first focus group was supposed to represent "European" or "Cosmopolitan" identifications, while the second one was supposed to lack the "pro-Western" orientations. However, it proved difficult to organize the focus groups by the principle "West versus East" because the question of (trans)national identity is highly complex in Belarus (as shown in the following sections). Differently than planned, the first focus group was eventually characterized by primary identifications with "European" and "Cosmopolitan" cultures but also with "Slavic" culture, while in the second group identifications with "European" culture prevailed. ${ }^{380}$

The interviewees were initially selected on the basis of their positioning toward underground culture; therefore, a portion of the respondents were supposed to identify with underground culture and music. The model "non-underground versus underground" in relation to popular music seemed to reflect the model of the "official and the alternative Belarusianness." Although the reality proved to be far more complex than a dichotomy model, it is remarkable that almost all "underground" and "subcultural" respondents were found outside of official institutions, while the majority of "non-underground" respondents were among those recruited by the CSPI. Among other topics, the focus was placed on participants' subjective perceptions of the terms "underground," "subculture," and "mainstream," as well as of "Belarusian," "European," or "Russian" culture. The focus groups and interviews showed that, on the one hand, these categories are perceived quite ambivalently, but on the other, they can generate a vivid discussion revealing a person's positioning and providing further insight into discourses taking place in society.

Overall, the participants of the interviews and focus groups were young adults ranged from 17 to 30 years, living in Minsk. The majority of them were Russian-speaking, while four interviewees were Belarusian speakers. All participants, except for one person, were currently studying or already had higher education. The respondents were people with different musical preferences - from punk rock, metal, folk and indie, to reggae, rap, pop or various forms of electronic music. Some of the interviewees expressed belonging to a subculture, such as punk, goth, skinhead, or hip-hop. Half of the interviewees, as well as some of the focus group participants, were professional or amateur musicians, and some respondents had a musical education. The interviews and focus groups were conducted in Russian. ${ }^{381}$ All names were changed.

379 The focus groups, each consisting of eight participants, were conducted in cooperation with Agnes Reiter, whose project deals with young Belarusians' dress behaviors and their role in identity constructions.

380 Many respondents simultaneously identified with Belarusian culture, which indicates that the perceptions of it are ambiguous and can represent the opposing "East-West" poles.

381 Because of an insufficient command of Belarusian, I had to ask Belarusian speakers for an interview in Russian. (It should probably be mentioned that I was born and grew up in Kazakhstan, not in Belarus.) 


\section{Popular Music in Belarus}

The genres of music involved in Belarusian contemporary music-making include rural repertoires, classical music, variety performance or "entertainment" music (Estrada), staged folklore, bardic performance, and pop and rock music ${ }^{382}$ (including electronic music in its diverse forms as well as styles that are only indirectly related to pop and rock, such as reggae and hip-hop). Figures 1 and 2 show general stylistic preferences of young Belarusians:

Fig. 1: Distribution of favorite music styles

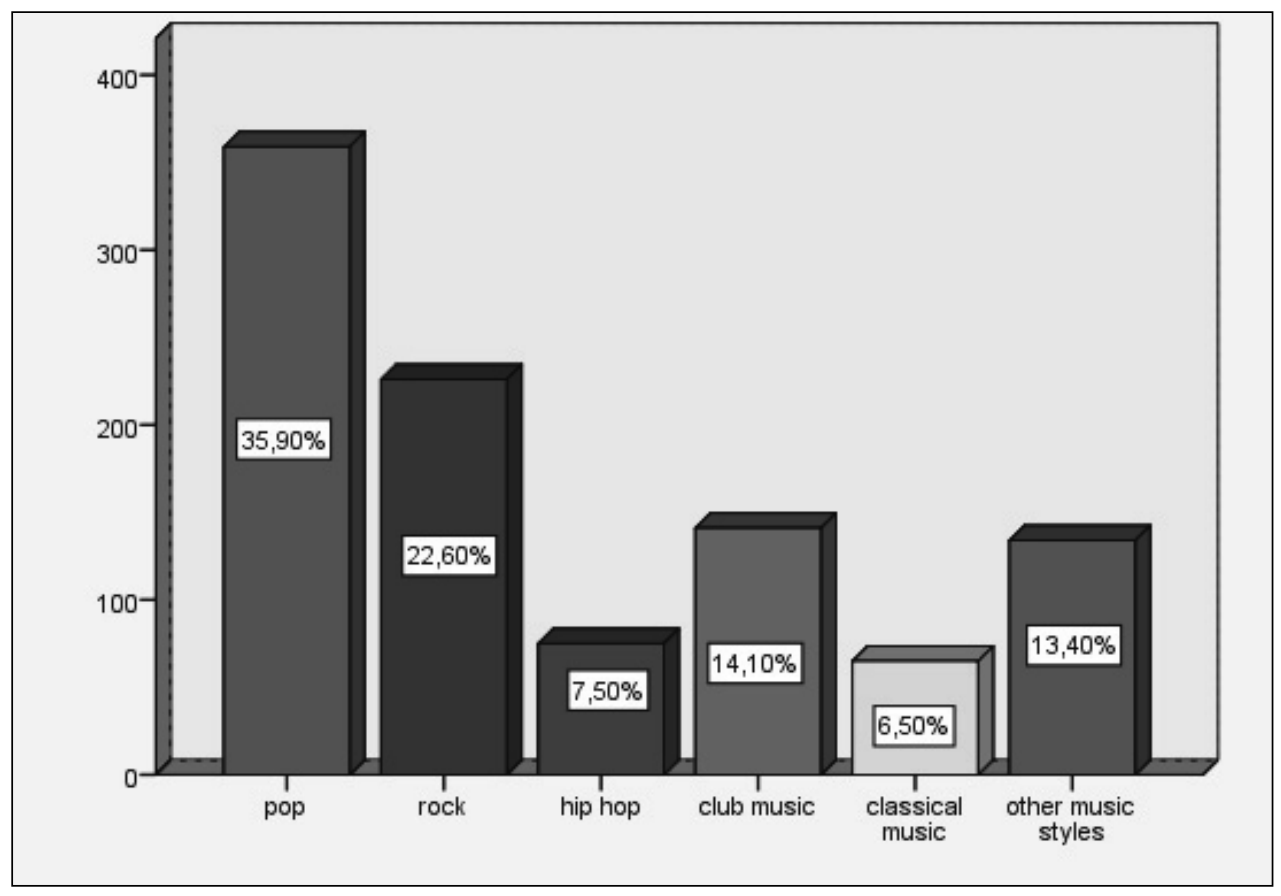

382 Cf. Maria Paula Survilla, Of Mermaids and Rock Singers: Placing the Self and Constructing the Nation through Belarusan Contemporary Music (New York and London: Routledge, 2002), 62. 
Fig. 2: Distribution of favorite live music

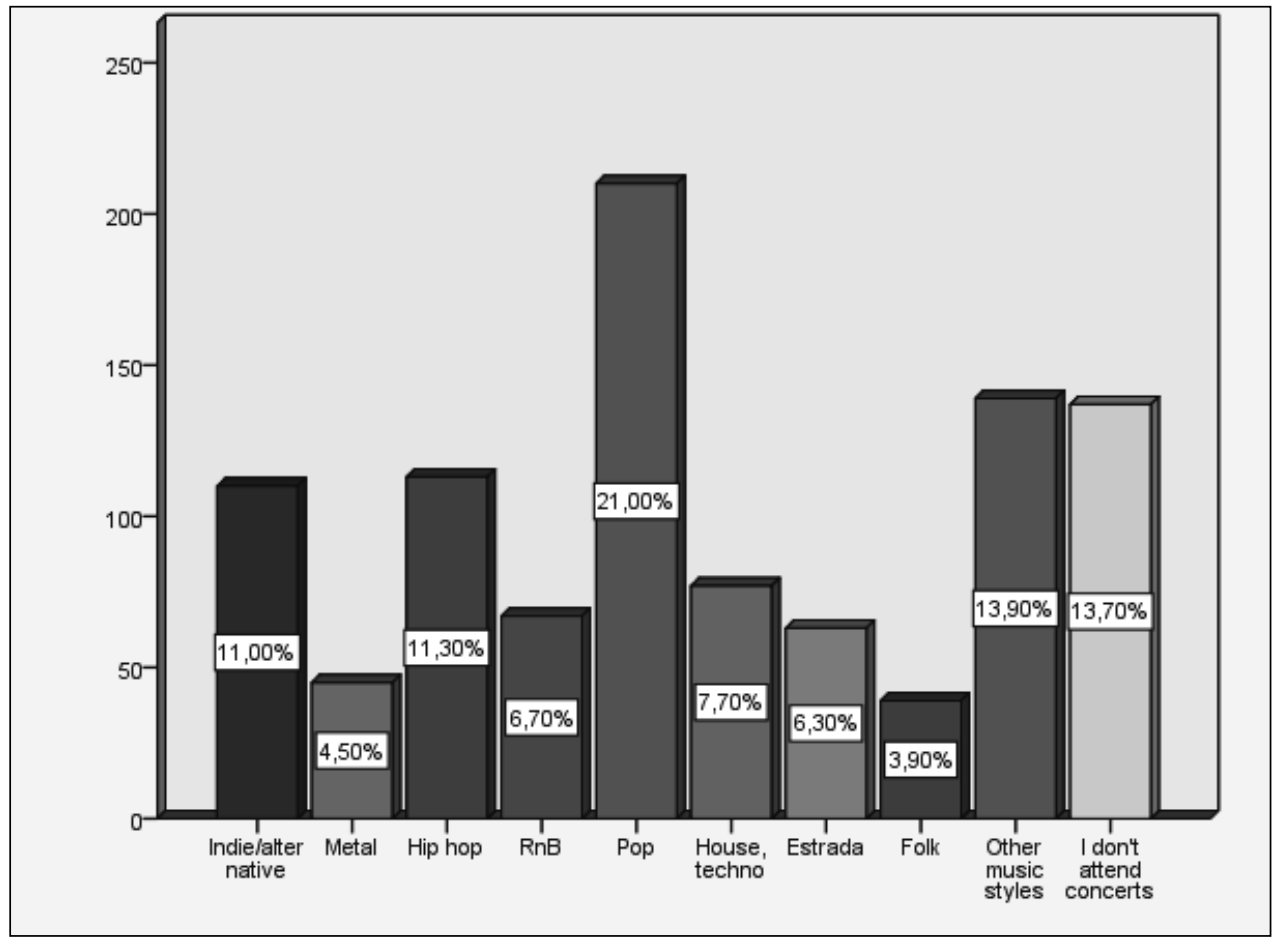

Figure 1 reflects the classical "pop-rock" division, although one should bear in mind that genres such as "pop" and "rock" are broad meta-categories and can be interpreted very differently. The graph showing live music preferences does not reveal such a division because, firstly, the respective question offers more options and, secondly, the meta-category of rock is split into several "sub-styles."

Russian and Western music is most widespread in Belarus. Music stores in Minsk usually offer Western, Russian and Belarusian music, but the latter often seems underrepresented. Overall, there is a marked lack of a music industry in Belarus. ${ }^{383}$ Languages that Belarusian musicians use in songwriting are, in most cases, Russian, Belarusian and English, with Russian being most preferred. It can be stated that Belarusian and especially Belarusian-language music has a marginal status in Belarus, compared to music from Russia and the Western countries. This is evidenced by the following statistics: in answering the question "What country's music do you prefer most?" 50 percent of the respondents indicated a preference for music from Russia, while a further 34 percent chose music

383 Cf. Maria Paula Survilla, "Belarus," in Continuum Encyclopedia of Popular Music of the World, VII, eds. John Shepherd, David Horn, and Dave Laing (New York: Continuum, 2005), 48-52. 
from the USA or Great Britain. ${ }^{384}$ Music of Belarus was indicated by 5,5 percent (see figure 3). Of these 5,5 percent (or 55 respondents), 30 persons indicated that the texts in music they prefer are in Russian, 9 respondents chose English, and 14 persons indicated Belarusian. This demonstrates the low proportion of Belarusian-language music in Belarusian music, as well as the low popularity of Belarusian-language music among young Belarusians. In the question "What further countries' music do you prefer?" Belarus was chosen by 15 percent, Russia by 22 percent, and USA/Great Britain by 26,5 percent of the respondents. These results indicate that Belarus as the "country of music's origin" occupies a marginal position in music preferences of young Belarusians, staying far behind Russia and the USA and Great Britain.

Fig. 3: Distribution of countries of favorite music's origin

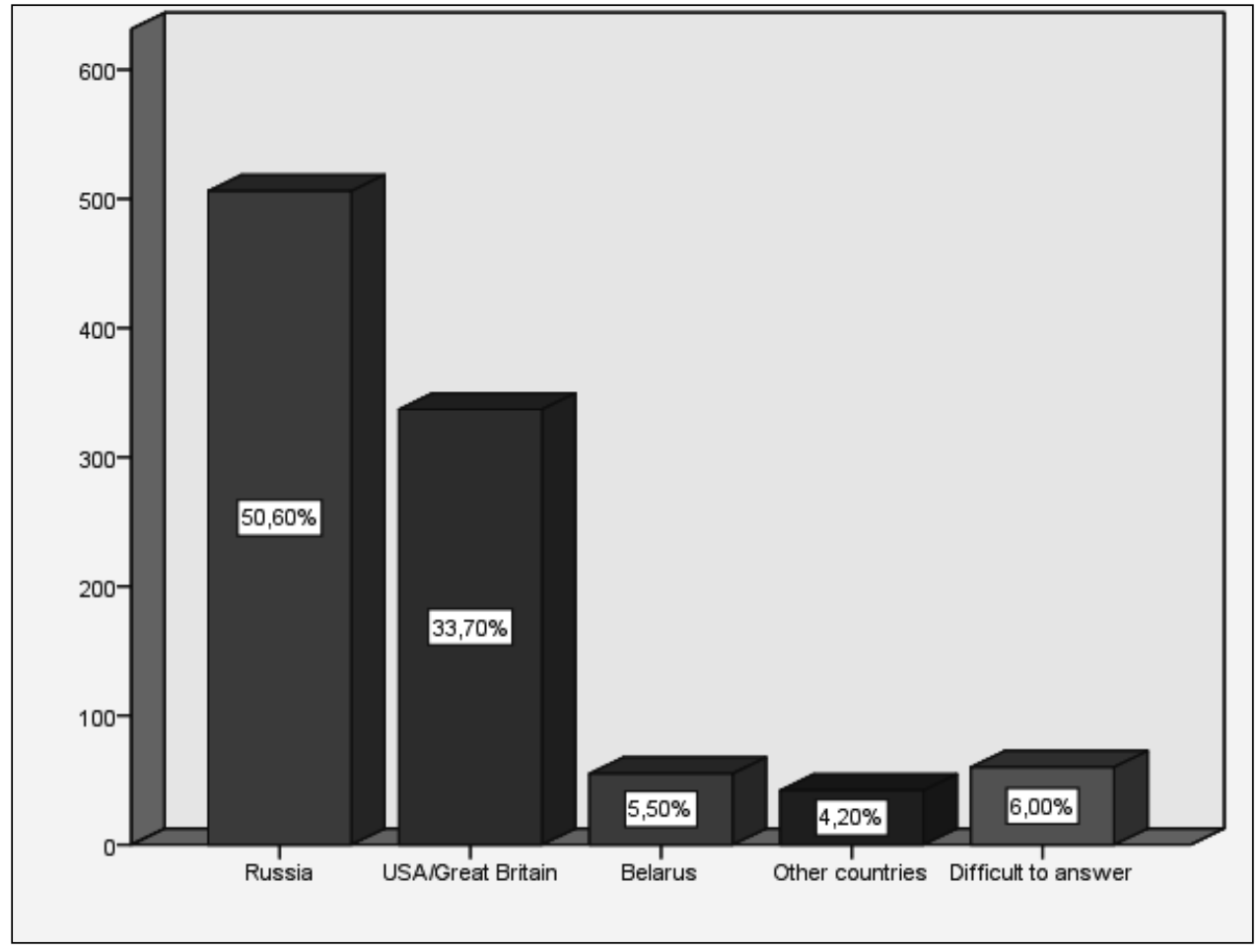

The distribution of language preferences in music is similar (see figure 4). Comparing the graphs in figures 4 and 5 reveals a parallel between preferences in music's languages

384 There is a discrepancy here between the survey data and the results of ethnographic research: while pop music and Russia as the "country of music's origin" prevail in preferences according to the survey data, the interviews and focus groups reveal that most people dissociate themselves from Russian pop music (generally labeled as popsa). 
and languages considered native. Nearly 52 percent of the respondents identified Russian as their native language, and 55 percent pointed to the Russian language in music they prefer. However, this parallel is obvious only in relation to the Russian language, not to Belarusian. While 35 percent of the respondents consider Belarusian their native language, less than two percent said that their favorite music's texts are written in Belarusian. This discrepancy can be explained, firstly, by the fact that considering a language native and actually speaking this language do not necessarily coincide in Belarus. Many Belarusians, who identify Belarusian as their native language, in fact speak Russian in everyday life: of the 35 percent of the respondents who consider Belarusian their native language, only 8,3 percent said that they use it in everyday life. Secondly, the music market is primarily provided with Russian and Western music rather than Belarusian, so it is hardly possible for Belarusian-language music to gain priority.

Fig. 4: Distribution of languages in favorite music

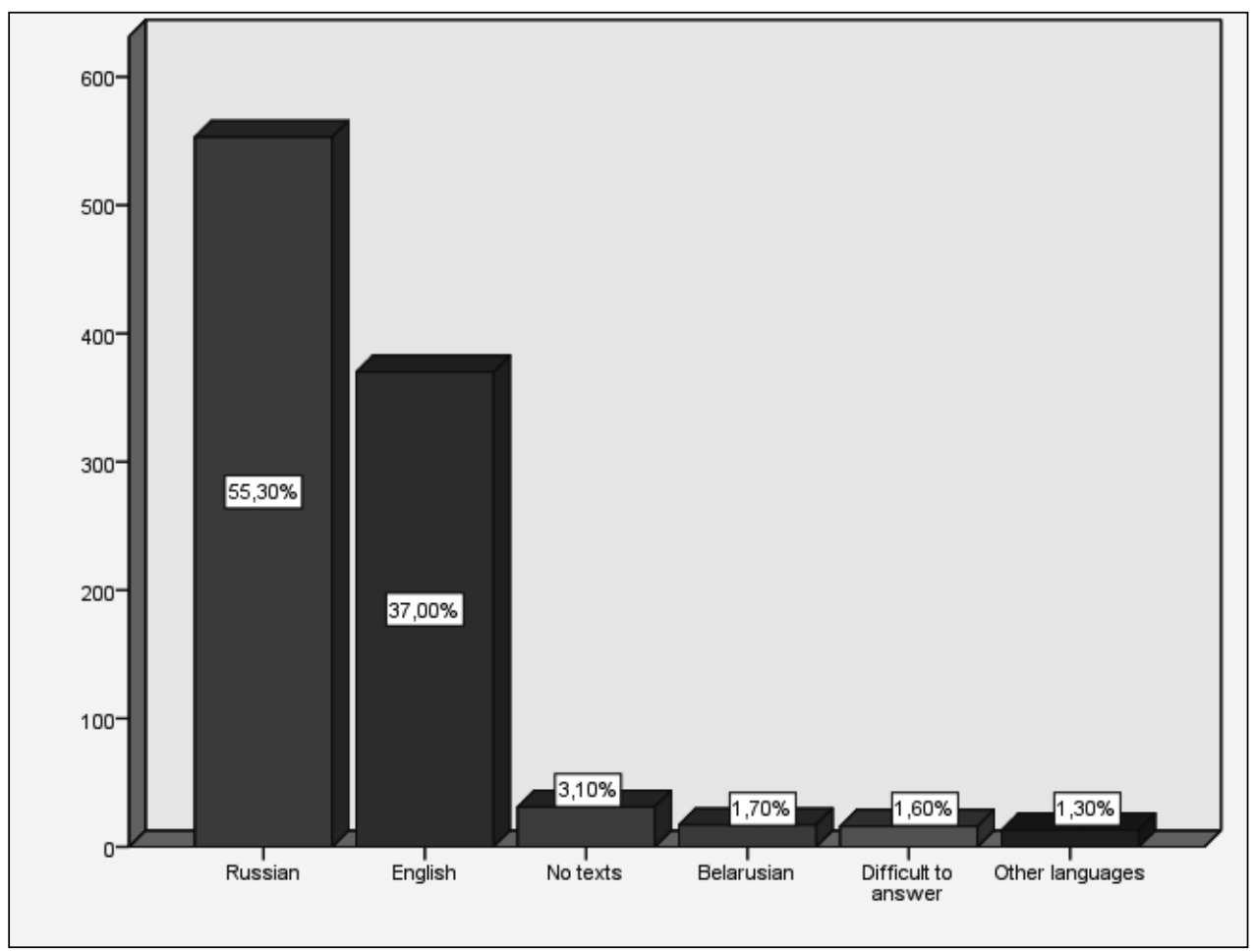


Fig. 5: Distribution of languages considered native

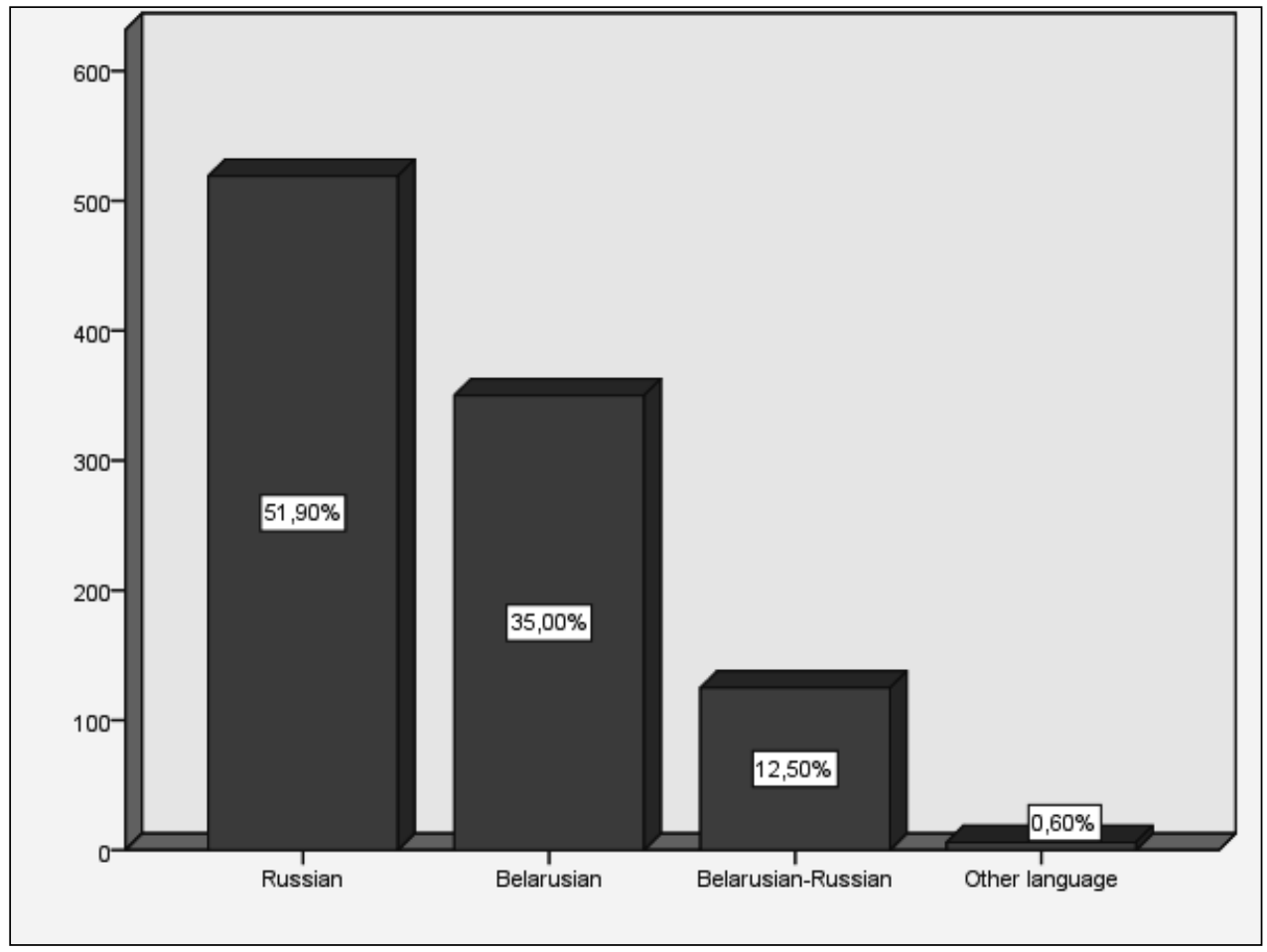

The responses to the question "In which further languages are your favorite music's texts written?" show that Belarusian is indicated by nearly 15 percent, Russian by 28 percent, and English by 41 percent of the respondents. Both the distribution of the "countries of preferred music's origin" and the distribution of "languages in favorite music" reveal that Belarusian music (which may be in Russian or English) as well as Belarusian-language music occupies a marginal position in music preferences of young Belarusians. This is also evident in the discourse on Belarusian music, as shown in the following section.

\section{The Discourse on Belarusian Music}

It is possible to emphasize three major aspects in the discourse on Belarusian music: the first aspect is in regard to Belarusian music's existence, which leads to the second aspect of the music's authenticity and, finally, to the third aspect of language. The aspects of the discourse are closely interconnected and flow into one another. Ultimately, they reflect the extremely complex perception of Belarusian culture by young people as well as their self-perception within this culture. 


\section{“Belarusian music doesn’t exist”}

To some respondents, the marginal position of Belarusian music raises the issue of its very existence. The topics of Belarusian music and Belarusian culture were often closely interlinked in the interviews and focus groups. As the following examples demonstrate, young people's perceptions of Belarusian culture vary significantly. Some of the respondents stated that Belarusian culture does not exist, and others supported this statement. "Nonexistence" of Belarusian culture is usually explained by the country's position between Russia and the Western states as well as by the inevitable influences of other cultures. Some respondents of focus group 1 pointed out that under these influences, Belarus has lost or never had its own identity, as can be seen from the following interview excerpts:

R4: As for Belarusian culture, I think there is practically no such notion. Because Belarusian culture is rather a formation of culture of Russia, Ukraine, the neighboring countries. It is connected rather with the history; it is a historical development. If in music there is some progress - it is made and becomes more popular... Then, as for Belarusian clothes - there are none. Everything is formed from the neighboring countries. We don't have a distinct Belarusian culture. There is something, but it is weak, I wouldn't consider it culture, if we speak just of clothes and music.

R3: I don't know any distinctive features of Belarusian culture. But people who work on that are trying to find Belarusian culture, to highlight what was destroyed in the Soviet Union, and to form it in the context of global culture. I am in the search, trying to find it to formulate it for myself. On the other hand, there are so many other cultures - Indian, African, American. To me, this is all interesting. The world is moving toward globalism. All we can do is our contribution, i.e. throw Belarusian culture into the global melting pot. R6: We are still a very young country. So the absence of culture is not a big catastrophe.

This passage reveals that "distinctiveness" of culture and music is viewed as a criterion of their existence. The attempts to discover and articulate differences between other cultures and one's own culture are clear evidence of the ongoing search for identity. As one of the respondents (R3) put it, he is "in the search" of Belarusian culture, while being interested in other cultures as well. Transculturality and national identity formation are, therefore, not mutually exclusive processes and can coexist within one person or group.

"Nonexistence" of Belarusian music is similarly explained by the lack of the music's distinctiveness. As one of the respondents of focus group 1 stated, Belarusian culture and music fail to be "unique" and are "lost" in other cultures:

Remaking and imitation, that's the dead-end development of Belarusian culture. [...] it is trying to become popular by copying. But it isn't unique; it just gets lost in European, in world culture. We have folk musicians, and that's the only thing that makes us different from the masses. [...] All the rest is European or world culture in miniature.

Some respondents expressed the opinion that Belarusian music is "backward" and lacks progress. It is usually compared with Western music, which is considered more innovative. 
Matvey says, "Everyone listens to Western music, [...] in Belarus there is no music, actually. [...] It doesn't develop at all, [...] it's backward. [...] We are behind [the West] because in Soviet times there was the iron curtain, when it was not allowed to listen to Western music." This attitude understandably produces disinterest in Belarusian music because it, in Matvey's words, "falls behind Western music for decades." The disinterest is also justified by the assumption that the state does not support and develop Belarusian culture and music, as some respondents claimed. Thus, eventually, beliefs in the "absence" of Belarusian music result from disinterest produced by assumptions of the music's "backwardness" and of the government's passive attitude toward Belarusian culture. Disinterest is also often explained by the music's imitative character. For example, Yuliya says:

No, I don't listen to Belarusian music, actually [...]. Maybe because I don't feel it's close to me.

Interviewer: Even Belarusian rock?

Yuliya: I would say there are very, very few such bands. And even if there are some bands excluding Lyapis Trubetskoy - they are so unknown that... How do I say that? Their music, I would say, doesn't have something distinct. As far as I know, our bands perform in English [or perform tributes.]

Mark made a similar statement about Belarusian music being a "copy" of something else: "On television, too, it's all very pitiful. If it's not ideology, then it's copies of something successful from the West or from Russia. There is nothing [of its] own." Terms such as "not unique," "copying" or "different from the masses" raise the issue of authenticity, which obviously plays a very important role in the perception of Belarusian music for many people. The quite common opinion that "Belarusian music doesn't exist" should therefore be understood as "Belarusian music that is distinct and authentic doesn't exist."

\section{Authenticity}

As Simon Frith has argued, the term "authenticity" is misleading. What should be examined is not how "true" a piece of music is, but how it constructs the idea of "truth." 385 Remarkably, the fact that music is made in Belarus often turns out to be insufficient for considering it "truly" Belarusian. As commonly believed, criteria for the music's authenticity are the use of traditional instruments and of the Belarusian language. The discourse on the "imitative" character of Belarusian music arguably has its roots in the Soviet culture politics, which propagated folk musics of Soviet republics with the use of native languages and traditional instruments. Folk repertoires were evaluated "as a contemporary

385 Simon Frith, Taking Popular Music Seriously: Selected Essays (Aldershot and Burlington: Ashgate, 2007), 261. 
musical mirror of a Soviet society united in work as well as in expression." 386 Folk music was regarded as authentic and genuine to the Soviet people, since it was the "music of the people." Popular music with folk components (such as the "vocal-instrumental ensembles") was appreciated, while Western rock music was represented as being the product of the antagonistic capitalistic world and of the "bourgeois" society, and therefore influences of Western music were often perceived extremely negatively. Soviet music that happened to reveal Western influences was devaluated, at least by official structures, as being "inauthentic." Soviet legacy arguably still plays a role in many discourses, including the discourse on Belarusian music and its authenticity. The "idea of truth" constructed around Soviet popular music is part of cultural memory, which in different, transformed ways can affect young people born after the fall of the Soviet Union, as evidenced by the respondents' claims about the imitative character of Belarusian music.

\section{Language}

The issue of language in Belarus plays an extremely important role in the perception of culture and music as authentic. In one of the focus groups, some respondents pointed out that Belarusian culture as a fusion of different cultures is unique, particularly, by being a fusion. Others similarly argued that Belarusian culture is distinctive and differs from other cultures. One of the respondents (respondent 4 of focus group 2) expressed the opposite opinion, saying that there is nothing "special" about Belarusian culture, which provoked a negative reaction from some others. She emphasized the importance of the language, and her doubt in the existence of Belarusian culture results from the fact that the Belarusian language is in a marginal position. Overall, the following passage demonstrates the diverse ways in which young people perceive Belarusian culture, and therefore is quoted at length:

Moderator: So, is there other cultures' influence? In the questionnaire, you indicated different answers to the question "What culture(s) do you identify with?" Some of you indicated "European," others chose "Russian" or "Belarusian." So how do you feel, what culture is closest to you, and why?

Respondent 6: I don't feel that Belarusians are part of Russia. In my opinion, we have our own culture, a Belarusian one, not like others. And I indicated two options - Belarusian and European - because tendencies of Europe are close to us. We communicate with Lithuanians and Poles. And I think it is important for us. I am part of European society. But this doesn't stop me from being part of Belarusian society.

R2: This, in my opinion, is what makes Belarusian culture unique. I believe that we do have our own culture. Although, when you read scientific literature, many authors state there is no Belarusian culture, it hasn't developed yet. Yes, it is young. And the uniqueness...

386 Maria Paula Survilla, "Rock Music in Belarus," Rocking the State: Rock Music and Politics in Eastern Europe and Russia, ed. Sabrina Petra Ramet (Oxford: Westview Press, 1994), 223. 
R4: So what makes it evident?

R5: What about our traditions? This is also culture. And they are not young at all.

R2: Traditions, it's clear. Unfortunately, they practically disappeared while we belonged to other states.

R6: They didn't die. They've been almost stifled but they are being reborn.

R2: Yes, they are stifled. And I would be glad if they were reborn again. And what makes our culture unique, it is a blend. We've always been between Europe and Russia (I almost said Asia). And I can't say for sure that I feel like part of Europe or Russia. I feel I am a Belarusian, and I'm glad that both Russian and European tendencies influence me.

R8: I would agree with Kseniya because throughout history, we've been a ping pong ball between Europe and the Russian Empire, which has somewhat negatively influenced us. Although they kind of say "Slavic brothers." But I'm not going into historical detail. But yes, we are a blend. A blend of cultures [...]

R5: I believe we have a distinct culture. Because if you simply judge by literature, Russian classics such as Pushkin and Lermontov and Belarusian classics are absolutely different.

[...] Belarusian festivities embody the old traditions [...]

R6: Ethnic weddings.

R5: Yes, yes, all that. And there is a lot of that. Our culture is individual, and it differs from others. It has similarities because it's close but...

R4: To me, the notion of culture is an ambiguous one. Especially the notion of Belarusian culture. I don't know why they say it's special. Traditions, what traditions have we adopted? Kupala is celebrated. What further Belarusian traditions? The key indicator of culture is language. How many percent do we have speaking Belarusian?

R5: Not everyone, but many, enough. Recently, I was buying guitar strings in a music shop, and there was a young man, a little older than me, who spoke pure Belarusian.

R2: That's just a single case.

R5: But still, there are such people.

R4: These are some sort of subcultures. But we are talking about Belarusian culture. Language is the key factor. Practically no one speaks Belarusian.

R6: This is our problem that no one speaks it.

These examples of articulation of culture illustrate young people's active search for identity. The discussion reveals several issues in the discourse on Belarusian culture. First, perceptions of what represents Belarusian culture vary; second, there are different opinions on whether Belarusian culture is distinct; and third, one can observe an awareness of the role of language for Belarusian identity. The passage demonstrates that for young Belarusians, it is obviously important to discover and articulate national identity, albeit in different ways. While some respondents express uncertainty in relation to Belarusian identity, others articulate it by means of the dissociation from Russia and, simultaneously, identification with the "European society," which indicates the perception of Belarus as part of Europe. Another view of Belarusian identity is that it is distinct and is neither "Russian" nor "European," albeit influenced both by Russian and European cultures. ${ }^{387}$

387 Some others dissociated themselves from the Soviet past or, on the contrary, emphasized "unity" of Slavic cultures and associated themselves with Russian or Slavic culture. 
However, many respondents of the interviews and focus groups express the ambiguous perception of Belarusian identity, which is inextricably linked with the issue of the Belarusian language. In other words, the marginal position of the language is one of the primary factors in the ambiguous self-perception as Belarusian. Many respondents articulated the difficulty in a complete identification with Belarusian culture because of insufficient command of Belarusian. The critical engagement with the issue of language is, therefore, a key factor in the ongoing processes of national identity formation.

However, the lack of use of Belarusian in everyday life can be compensated by cultural practices different from language use, and particularly by music. The following passage from the interview with Aleksandr demonstrates the symbolic meaning of cultural practices in the process of identity construction:

To me, Belarusian culture is something intelligent and forgotten... You can't call it guilt that I am a Belarusian and don't speak Belarusian, but there is something in it. If I see an opportunity somewhere to express myself as a Belarusian, I do that. For instance, I choose the Belarusian language in a computer program and I listen to Belarusian music. Or I have a t-shirt with the $\breve{\text { Y }}$ print. ${ }^{388}$ Indeed these are small things but still I like to do that.

Many respondents perceive their insufficient command of Belarusian as a negative phenomenon that results from the country's historical developments. Some of them, indeed, seem to have feelings of guilt and embarrassment because of not speaking Belarusian, as Aleksandr suggested. In such cases, Belarusian-language music has a function of compensation and is favored, among other meanings that the music offers, as a language practice. In this way, by means of music, the Belarusian language is made an everyday practice without the necessity to actually speak it in everyday life.

The Belarusian language often seems to have a symbolic meaning for Belarusian identity. In music making and music preferences, the symbolic meaning of the language is especially evident. Boris describes himself as an apolitical skinhead of the SHARP movement ${ }^{389}$ and plays guitar in a punk-hardcore band. He identifies with Belarusian culture (which he perceives as having European roots) and speaks Russian but considers it important for the band to have songs in Belarusian in order to be able to properly represent Belarus abroad:

Interviewer: Do you have a good command of Belarusian?

Boris: I do, but I kind of don't care about speaking it. There are people who are crazy about all that. But I... I grew up in Russian, was brought up in Russian...

Interviewer: Still, you write your texts in Belarusian as well.

$388 \ddot{\mathrm{y}}$ is a sign of the Galereya $\breve{\mathrm{Y}}$, a gallery in Minsk, which promotes Belarusian-language literature and

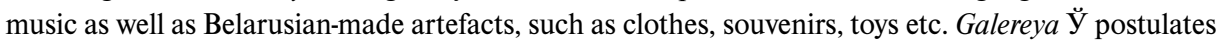
itself as a mediator of Belarusian culture and is a meeting point for young Belarusian speakers.

389 The term "SHARP” stands for "Skinheads Against Racial Prejudice." 
Boris: Well, of course. But that's more for people from other countries, so that they know how our language is, how our culture is. Our lead singer [...] doesn't speak Belarusian either but nonetheless, he appreciates Belarusian culture very much.

The symbolic use of the language obviously functions as a means of maintaining authenticity of the music for Boris and his band. It is important to them to be able to represent Belarus in a way that would emphasize its difference from other countries: by means of the language of the lyrics. In this way, musicians construct authenticity of their music (and of themselves).

Belarusian-speaking respondents, who were in a minority, favored Belarusian music, and particularly Belarusian rock. The latter is often associated with nationalistic attitudes. Belarusian rock as an expression of Belarusian identity offers Belarusian speakers a sense of national identity. ${ }^{390}$ Maksim's words support this observation: "It is obvious that in Belarus, Belarusian culture is suppressed, trampled down, and it's going on... And often those who are interested in Belarusian culture, their own culture, among those people there are many, who listen to Belarusian-language music, Belarusian music and so on." Maksim would fall within the concept of conscious "alternative Belarusianness": ${ }^{391}$ he speaks Belarusian in everyday life and maintains a pro-Western attitude as well as criticism of Russia's political and cultural influence in Belarus. He prefers Western and Belarusian music, which is mainly rock, folk rock and folk metal. To him, the existence of Belarusian music is undeniable, and is dependent on the level of interest in one's "own" culture. In Maksim's opinion, every Belarusian, who considers herself as such, should and will appreciate both the Belarusian language and music.

It is eventually important to mention that some Belarusian-speaking respondents feel irritated by the "demonstrative function" of language in music, as well as by politicization of Belarusian-language music (especially rock and rap). In their opinion, Belarusian music should be appreciated not for the use of language, but for aesthetic or expressive qualities. For example, Belarusian-language rapper Mark explains, "Of course I identify with Belarus and consider myself a Belarusian, but I don't like it when they make music in Belarusian just for it to be in Belarusian." He adds, "The language as well as music is a means to express oneself" and should not be politicized because politicization restricts both the language and music. Stas similarly claims that "music is music" rather than a "political instrument." The respondents' view of Belarusian music reveals another dimension in the articulation of identity: they dissociate themselves from the "demonstrative" use of language and regard it purely as a means of communication and self-expression, which indicates an aspiration of "Belarusianness" as a state of mind, not as an indicator

390 Paula Maria Survilla, Of Mermaids and Rock Singers: Placing the Self and Constructing the Nation through Belarusan Contemporary Music (New York and London: Routledge, 2002).

391 Nelly Bekus, Struggle over identity: the official and the alternative "Belarusianness" (Budapest: CEU Press, 2010). 
of political attitudes. This, as concluded from their considerations, is the only way for the future of Belarusian culture, language, and music.

\title{
Summary
}

The discourse on Belarusian music reveals the extremely complex perceptions of Belarusian culture and indicates a continuing process of identity formation of young Belarusians. This is mainly evidenced by the aspect of authenticity expressed in the attempts to discover and articulate the difference of Belarusian culture and music from other cultures and musics. The difficulty in articulating this difference leads to disinterest in Belarusian music, which in turn results from such themes of the discourse as "nonexistence," "lack of uniqueness" or "backwardness" of Belarusian music. The discourse is organized around the issue of the Belarusian language in Belarus and often seems to be influenced by young people's awareness of insufficient command of Belarusian. Unpopularity of Belarusian-language music among young Belarusians reflects the status of the Belarusian language. Belarusian music represents a cultural landscape that reveals the issue of the language in Belarus, i.e. the lack of Belarusian in most people's everyday lives. Both the Belarusian language and Belarusian music often have a symbolic meaning for Russian speakers. The symbolic meaning of Belarusian music eventually facilitates the construction of Belarusian identity without using the language as an everyday practice. Belarusian music can thus fulfill the functions of compensation and authentication. For some Belarusian speakers, Belarusian music and language represent a resource through which they construct and articulate conscious positioning of (proWestern) Belarusianness; for others, the music and language represent an aspiration toward cultural self-expression as Belarusians beyond politics.

\section{A Discourse on Belarusian Music and its Role in the Construction of Identities in Belarus}

\begin{abstract}
Issues of national identity remain a topic of great importance in Belarus, the state between "East and West". In this article, I identify the discourse on Belarusian music taking place among young Belarusian adults. This discourse is centred on three major aspects: the very existence of a distinct Belarusian music, its authenticity and the aspect of language. The article attempts to demonstrate that the discourse, characterized by young people's ambivalent perceptions of Belarusian culture and music, reflects the ongoing process for the search for identity. The complexity of the notion of Belarusian culture and the ambiguity of the term "Belarusian identity" is linked with the issue of the Belarusian language, which occupies a marginal position in Belarus. In this article, I analyse
\end{abstract}


the interconnection of the perceptions of music, culture and language in Belarus, and identify the functions which Belarusian music fulfils, both for Belarusian- and Russianspeaking Belarusians.

\title{
Hudba a její role v procesu tvorby identit v Bělorusku
}

\begin{abstract}
Abstrakt
V Bělorusku, ve státě ležícím mezi „Východem” a „Západem“, zůstávají otázky národní identity zásadním tématem. Studie představuje diskurz běloruské hudby mezi mladými dospělými lidmi v Bělorusku. Zmíněný diskurz vychází ze tř́i klíčových aspektů: jde o samotnou existenci specifické běloruské hudby, její autenticitu a s tímto související jazykový aspekt. Cílem studie je ukázat, že diskurz, charakterizovaný ambivalentními postoji mladých lidí $\mathrm{k}$ běloruské kultuře a hudbě, reflektuje pokračující proces hledání identity. Komplexní charakter kultury v Bělorusku stejně jako víceznačnost „běloruské identity“ souvisí s problematikou běloruského jazyka, v daném prostředí hrajícího spíše okrajovou roli. Studie analyzuje provázanost vnímání hudby, kultury a jazyka v Bělorusku. Dále identifikuje funkce, které běloruská hudba plní jak pro populaci mluvící bělorusky, tak pro občany, jejichž primárním jazykem je ruština.
\end{abstract}

\section{Keywords}

Authenticity; Belarusian music; cultural practice; discourse; identity; popular music.

\section{Klíčová slova}

Autenticita; hudba v Bělorusku; kulturní praxe; diskurz; identita; populární hudba. 